\title{
Homenagem à Professora Dulcimara Carvalho Nannetti
}

Dulcimara Carvalho Nannetti é professora do IFSULDEMINAS (Instituto Federal de Educação, Ciência e Tecnologia do Sul de Minas Gerais), campus Machado. Leciona a disciplina de solos no curso técnico em agropecuária; de fertilidade do solo na graduação em agronomia; de fertilidade do solo e nutrição de plantas no curso superior de tecnologia em cafeicultura; e de fertilidade do solo na pósgraduação em cafeicultura empresarial.

Sua atividade docente se combina com a coordenação de pesquisas em fertilidade e nutrição de plantas, bem como com a participação no Núcleo Institucional de Pesquisa e Extensão (NIPE) e nos colegiados dos cursos de agronomia e tecnologia em cafeicultura.

Dulcimara privilegiou a fertilidade do solo e a nutrição de plantas em suas pesquisas, focando-as principalmente na cafeicultura, atividade mais importante no sul de Minas e eixo do curso de Tecnologia em Cafeicultura. Orientou alunos desse curso, e eles apresentaram os resultados de suas pesquisas em eventos científicos, e publicaram artigos em periódicos como Coffee Science e Revista Brasileira de Ciência do Solo.

Alguns de seus projetos de pesquisa, articulados com produtores rurais e cooperativas, abordam temas como uso de superdosagem de fósforo e gesso agrícola; substituição de calcário por silicato de cálcio e magnésio.

Natural da cidade mineira de Machado, graduou-se em engenharia agronômica na Escola Superior de Agricultura e Ciências de Machado (ESACMA). Na Universidade Federal de Lavras (UFLA), concluiu o curso de mestrado (1994), ingressou como professora visitante no Departamento de Biologia, e terminou com sucesso o curso de doutorado em 2001.

Em 1995, Dulcimara foi aprovada em concurso público para professora efetiva de agropecuária na Escola Agrotécnica Federal de Machado, hoje campus Machado do IFSULDEMINAS. Como coordenadora da Unidade Educativa de Produção de Agricultura 1 do Setor de Olericultura, implementou as estufas de produção de mudas, de olerícolas com fertirrigação e de hidroponia. Tais incrementos permitiram que os estudantes de Machado se iniciassem no campo da pesquisa.

Também atuou no IFSULDEMINAS como supervisora pedagógica e coordenadora do CIEC (Coordenadoria de Integração Escola-Comunidade).

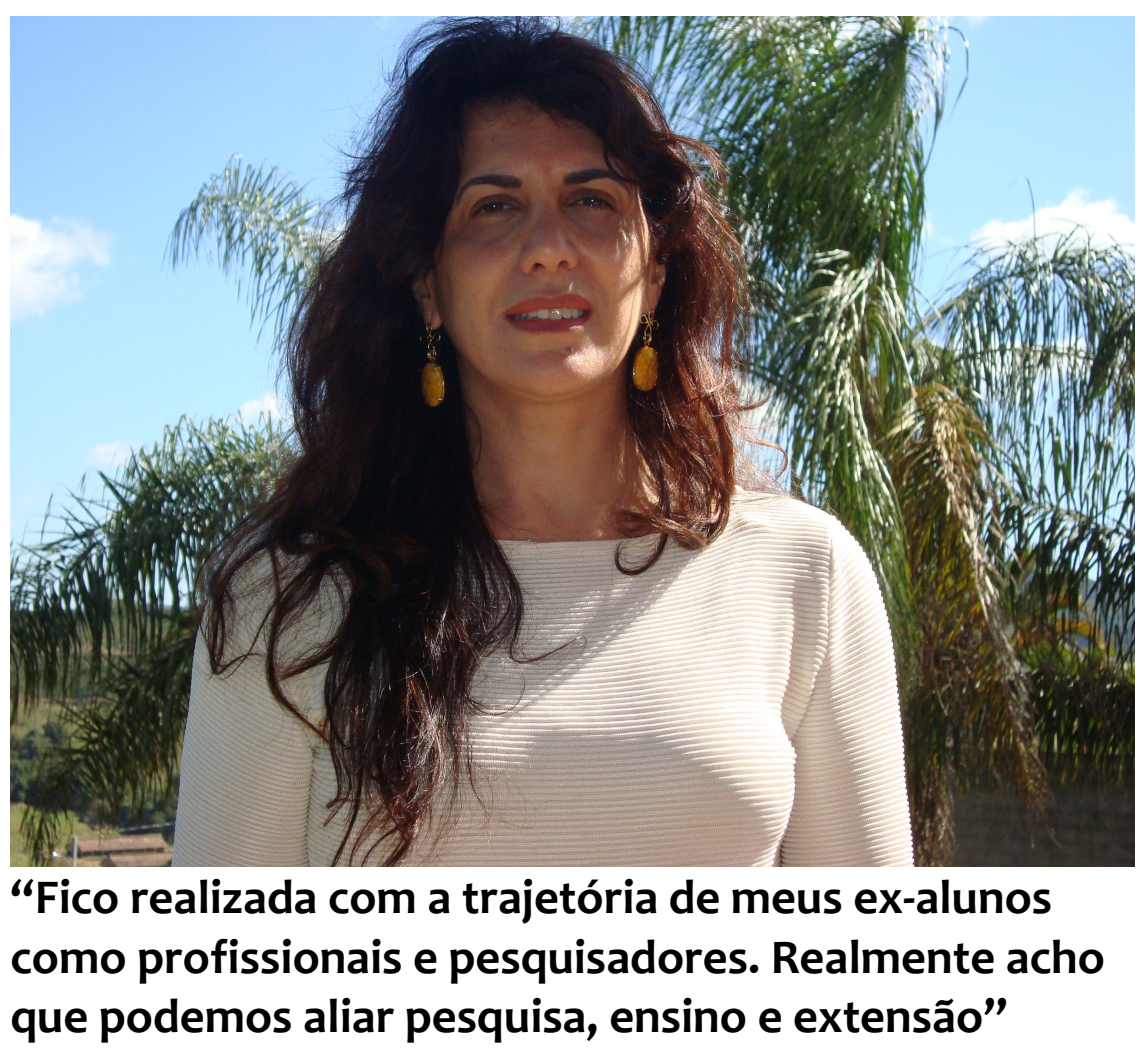

